\title{
Seismic Fortification Analysis of the Guoduo Gravity Dam in Tibet, China
}

\author{
Peng Lin, ${ }^{1}$ Wenwei Zheng, ${ }^{2}$ Bo Huang, ${ }^{3}$ and Haichao Zhang ${ }^{4}$ \\ ${ }^{1}$ State Key Laboratory of Hydroscience and Engineering, Tsinghua University, Beijing 100084, China \\ ${ }^{2}$ China Academy of Building Research, Beijing 100013, China \\ ${ }^{3} \mathrm{MOE}$ Key Laboratory of Soft Soils and Geoenvironmental Engineering, Department of Civil Engineering, Zhejiang University, \\ Hangzhou 310058, China \\ ${ }^{4}$ Guiyang Hydroelectric Investigation and Design Institute, China Hydropower Engineering Consulting Group Co., \\ Guiyang, Guizhou 550081, China
}

Correspondence should be addressed to Peng Lin; celinpe@tsinghua.edu.cn

Received 26 July 2014; Accepted 12 September 2014

Academic Editor: Bo Chen

Copyright (c) 2015 Peng Lin et al. This is an open access article distributed under the Creative Commons Attribution License, which permits unrestricted use, distribution, and reproduction in any medium, provided the original work is properly cited.

\begin{abstract}
The primary aim of this research was to analyze the seismic performance of the Guoduo gravity dam. A nonlinear FEM method was implemented to study the deformation, stress, and overall stability of dam under both static and dynamic loading conditions, including both normal and overloading conditions. A dam seismic failure risk control method is proposed based on the cracking mechanism induced by the dynamic load to ensure dam safety and stability. Numerical simulation revealed that (1) under normal static and dynamic loading the symmetry of the displacement distributions is good, showing that the dam abutments and riverbed foundation have good overall stiffness. The stress distribution is a safe one for operation under both normal water loading and seismic loading. (2) Attention should be paid to the reinforcement design of outlets of the diversion dam monoliths, and enhance the capability of sustaining that tensile stress of dam monoliths. (3) The shape of the dam profile has a significant effect on the dynamic response of the dam. (4) By employing the "overload safety factor method," the overall seismic fortification is as follows: $K 1=1.5, K 2=2 \sim 3$, and $K 3=3 \sim 4$.
\end{abstract}

\section{Introduction}

During the last 30 years, over 2000 dams have been constructed for irrigation, energy production, flood control, and recreation purposes in China. Almost 500 large dams have been built on the fringes of the active seismic zone in southwestern provinces in China. Since the failure of dams incurs great losses to society [1-5], all countries pay careful attention to dam safety, especially to those dams exposed to extreme earthquake loading [6-9]. In studying the seismic performance of the different types of dam and other civil structural, field surveys $[10,11]$, health monitoring $[12,13]$ and numerical simulation $[3,14,15]$ are important research tools. Computational mechanics has made a strong impact on classical continuum mechanics, which includes engineering and structural mechanics [16-18]. Earthquake engineering has made significant progress with the aid of computational mechanics [19-22]. The overall structural assessment of concrete gravity dams has long been undertaken. The first attempts to apply the theories and methods of fracture mechanics to concrete structures date back to the 1970 s [19]. Pioneering analyses were mostly based on linear elastic fracture mechanics (LEFM). Some case studies [20] were based on LEFM theories, including the analysis of cracking in the Fontana dam (USA), the Koyna dam (India), and the Köhlbrein dam (Austria). When nonlinear fracture mechanics (NLFM) models are used [21], a nonlinear dynamic problem has to be solved [22]. The latter nowadays is most challenging due to the large differences in the characteristic time scales of the problem.

During the development of structural seismic theory and analysis methods $[6,7]$, the three dominant approaches are 
based on static theory, pseudostatic theory, and dynamic theory. Static theory assumes the foundation is a continuous homogeneous rigid body. In the 1978 specifications for the seismic design of hydraulic structures seismic load is determined by a simplified, more realistic, pseudostatic method. The method is not really precise; however, dynamic theory is much more realistic because when calculating seismic action, comprehensive consideration of the structure and its natural vibration properties and damping factors is closer to the actual situation. Dynamic theory calculation ultimately comes down to solving the equations of motion of the structure. Two main solution methods are used: (1) the response spectrum method, for the seismic design of damping ratio of the elemental points system in the earthquake under the action of the maximum acceleration response of the curve of the change. The system natural vibration period is generally expressed by the ratio of the maximum peak ground motion acceleration. Standard response spectrum which is shown by the acceleration spectrum is widely used in the calculation of hydraulic structure and has a series of results that can be compared. (2) The time history method is based on the second order differential equations which describe the motions throughout the structure, equations solved by numerical integration, over time in small time increments $\Delta t$ in an essentially step-by-step integration method. The above two time domain methods fall into the category "timedomain analysis of structural responses."

In the last 30 years, much research aimed at studying the seismic fortification of dams has been carried out. Bouaanani and Renaud [23] presented an original investigation of the sensitivity of floor accelerations in gravity dams to various modelling assumptions relating to impounded reservoirs leading to analytical and coupled dam-reservoir finite element models. Li et al. [24] investigated seismic fortification of the Three Gorges dam based on experimental and numerical methods. Paggi et al. [25] took a multiscale approach for the seismic analysis of concrete gravity dams. Some researchers [26-28] analyzed the nonlinear seismic responses of arch dams caused by nonuniform ground motions and the influence of past loading history [29] and spatial variation inputs [30]. Valamanesh et al. [31] presented an application of the endurance time method for seismic analysis of concrete gravity dams; Omidi et al. [32] employed a plastic-damage model using different damping mechanisms to simulate the seismic cracking of concrete gravity dams. Ftima and Léger [33] used rigid block models to analyze the seismic stability of cracked concrete dams. All these studies were effective in analyzing the seismic response of dam structures, and many interesting stability assessment related results were obtained.

The primary aim of the authors' research was to analyze and understand the seismic performance of the Guoduo dam under complex geological conditions. The deformation, stress, cracking risk, and overall seismic stability of the Guoduo were analyzed using a 3D finite element method, under various dynamic and static loadings, and a description is given below. A dam seismic failure risk control method is proposed based on the cracking mechanism induced by the dynamic load to ensure dam safety and stability.

\section{Seismic Fortification Analysis Method and Cases}

2.1. Introduction to the Guoduo Gravity Dam. The Guoduo hydropower station (Figure 1) includes an under construction dam situated on the Zaqu River in Cangdu County, Tibet. The dam is a roller compacted concrete (RCC) gravity dam with a maximum height of $93 \mathrm{~m}$, a length of $235 \mathrm{~m}$, and a width of $8 \mathrm{~m}$ at the crown of the dam, respectively, and a maximum bottom width of $83.2 \mathrm{~m}$. The control river area is $33470 \mathrm{~km}^{2}$. The normal water elevation level (EL) is $3418 \mathrm{~m}$ and the corresponding capacity is 0.08 billion $\mathrm{m}^{3}$. The primary purpose of the Guoduo hydroelectric power station is to generate $160 \mathrm{MW}$ power for Tibet.

The dam site valley is wide "V" shape, and the slope topographies are relatively good. The left bank terrain slopes at $35^{\circ} \sim 40^{\circ}$, and the right abutment is steep, with consideration necessary for a $40^{\circ} \sim 45^{\circ}$ slope. The main hydraulic structure plane and profile layout are illustrated in Figure 1(b). The lithology of the left abutment is sandstone mudstone, J1ch1, between EL 3400 3435 m. Sandstone, J1ch2, siltstone, mudstone, and silt mudstone layers are distributed above EL $3435 \mathrm{~m}$. Below EL $3400 \mathrm{~m}$, the dam foundation and the right abutment (T3d2) consist of gray thick massive sandstone and siltstone with mudstone. The content of the sandstone and siltstone is high at about $80 \%$ of the dam foundation rock mass. The dam site contains six small faults ( $f 2, f 3, f 4$ and $\mathrm{f5}, \mathrm{f6}$, and $\mathrm{f7}$ ). Based on rock mass classification for dam foundations, there is IIIIA type rock mass (Tables 1 and 2) of sandstone and siltstone and IVC type rock mass of mudstone, argillaceous siltstone downstream of the dam site. The gravity dam foundation rock mass is mainly of type T3d2, a hard rock, especially the III1A class. The high strength and hard dam foundation rock mass has the bearing capacity to meet the design requirements. However, the concentrated soft rock area presents a problem of uneven deformation threatening the stability of gravity dam foundation. The left abutment was a reverse slope. An approximately $140 \mathrm{~m}$ high slope was formed after excavation. The slope is partially unstable due to sliding blocks. The right abutment is an inclined cut slope, $115 \mathrm{~m}$ high after excavation. This slope, influenced by lithology and the structure surface, may easily incur a bedding slip.

The dam site has a better than $10 \%$ probability in 50 years of a bedrock horizontal peak acceleration of $0.09 \mathrm{~g}$. The horizontal seismic acceleration criterion was of the Guoduo's hydraulic structure $0.09 \mathrm{~g}$. Dynamic loads generated by seismic disturbances must be considered in the design of concrete dams situated in recognized seismic high-risk regions. The possibility of seismic activity should also be considered for dams located outside those regions, particularly when sited in close proximity to potentially active geological fault complexes.

2.2. Numerical Modelling. The 3D nonlinear finite element dynamic analysis code, ABAQUS [34], was employed in this study. The dam-foundation-reservoir system, dam transverse 


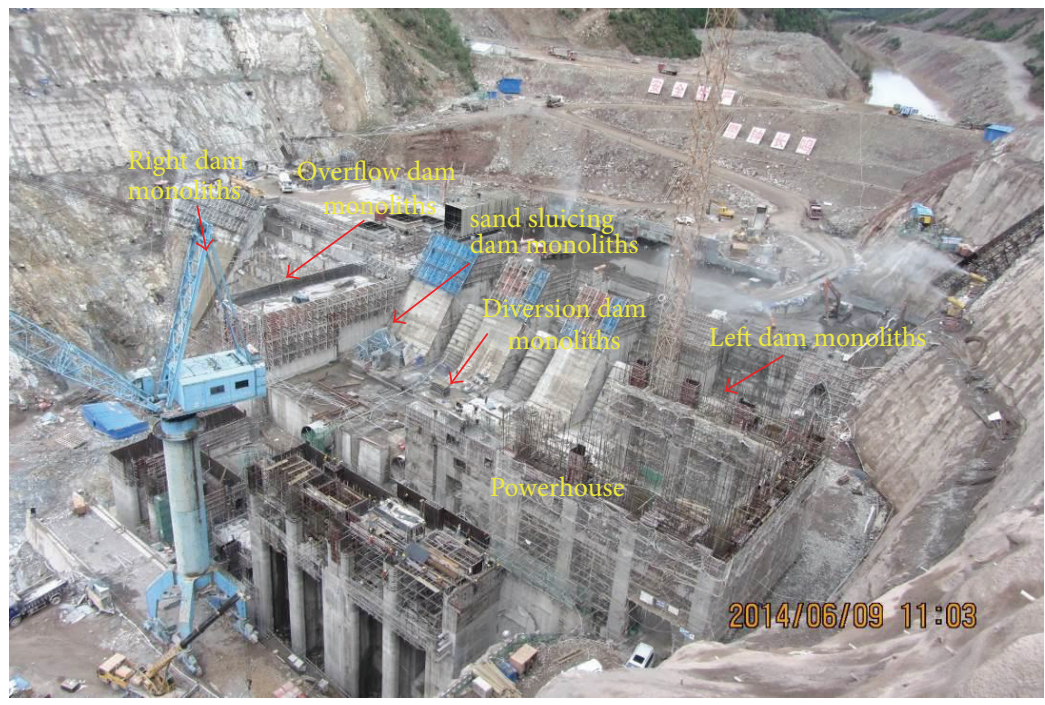

(a) Snapshot of the Guoduo gravity dam under construction

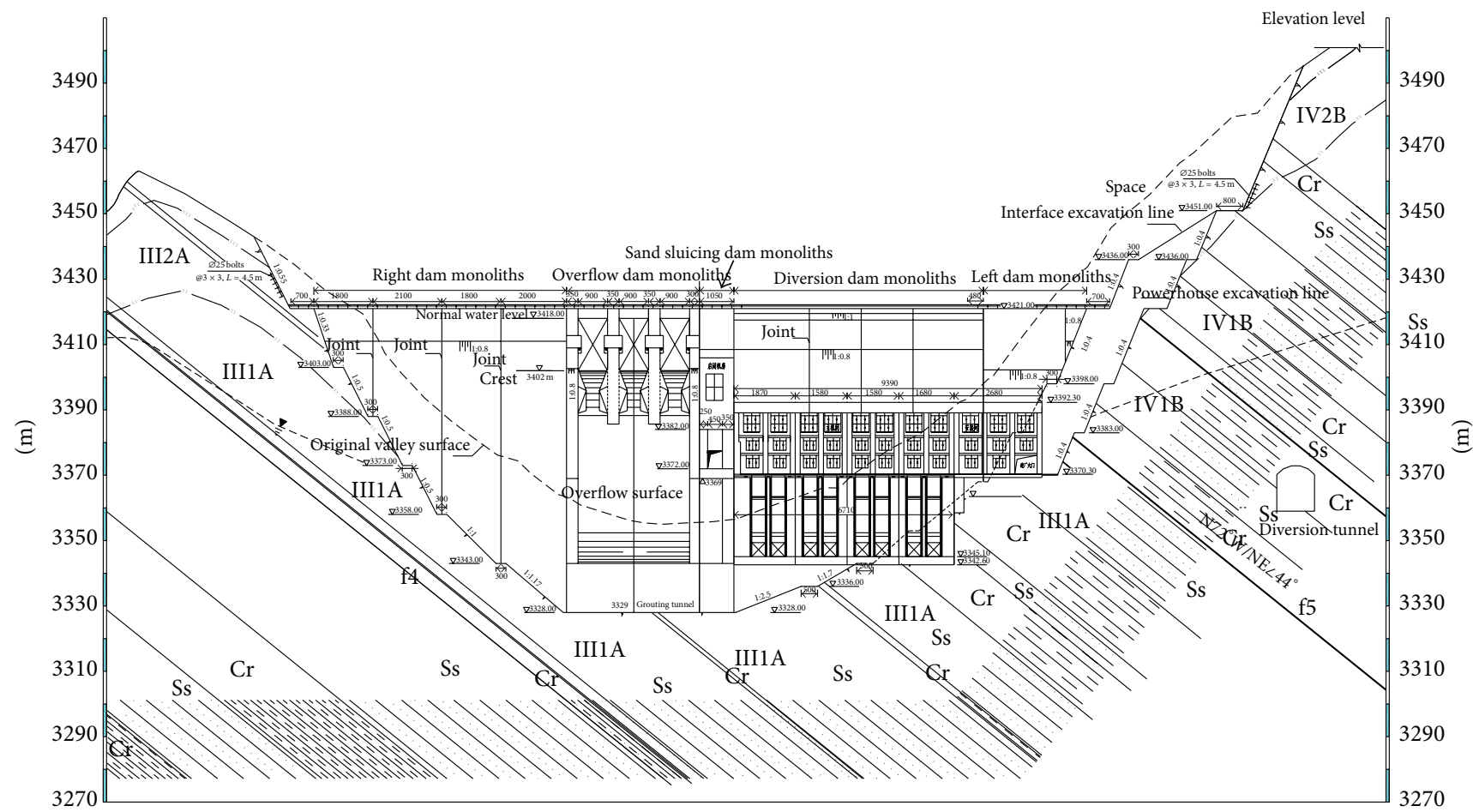

$\begin{array}{ll}\text { Ss Sandstone, siltstone } & \text { Sandstone } \\ \text { Cr Mudstone and silty mudstone }\end{array}$

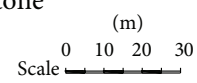

(b) Vertical profile of the Guoduo dam in the downstream side

FIgURE 1: Geoconditions and vertical profile of the Gouduo gravity dam.

joints, and dam induced joints were simulated under normal and overloading conditions. The 3D finite element analysis adopts the Drucker-Prager (D-P) yield criterion, which can be expressed by (1).
The 3D finite element analysis adopts Drucker-Prager (D$\mathrm{P})$ yield criterion, which can be expressed in

$$
f=\alpha I_{1}+J_{2}^{1 / 2}-H=0,
$$


TABLE 1: Physical-mechanical parameters of the concrete dam, the rock mass, and faults.

\begin{tabular}{|c|c|c|c|c|c|c|}
\hline \multirow{2}{*}{ Material } & \multirow{2}{*}{ Density $\left(\mathrm{t} / \mathrm{m}^{3}\right)$} & \multirow{2}{*}{ Permit load (MPa) } & \multirow{2}{*}{ Elastic modulus (GPa) } & \multirow{2}{*}{ Poisson's ratio } & \multicolumn{2}{|c|}{ Effective shear strength } \\
\hline & & & & & $C^{\prime}(\mathrm{MPa})$ & $f^{\prime}$ \\
\hline Dam (concrete) & 2.40 & 2.0 & 22 & 0.167 & 0.90 & 1.2 \\
\hline III2A & 2.61 & 3.4 & 8.8 & 0.32 & 0.70 & 0.80 \\
\hline III1A & 2.70 & 5.0 & 17.0 & 0.30 & 0.90 & 1.00 \\
\hline IV2B & 2.63 & 2.0 & 6.0 & 0.30 & 0.50 & 0.70 \\
\hline IV1B & 2.68 & 3.5 & 9.0 & 0.28 & 0.80 & 0.90 \\
\hline Weak rock layer of right bank & 2.4 & 1.0 & 1.5 & 0.30 & 0.05 & 0.40 \\
\hline Fault f2 & 2.4 & 1.0 & 1.5 & 0.30 & 0.05 & 0.35 \\
\hline Fault f3 & 2.4 & 1.0 & 1.5 & 0.30 & 0.05 & 0.35 \\
\hline Fault f4 & 2.4 & 1.0 & 1.5 & 0.30 & 0.05 & 0.35 \\
\hline Fault f5 & 2.4 & 1.0 & 1.5 & 0.30 & 0.05 & 0.35 \\
\hline Fault f7 & 2.4 & 1.0 & 1.5 & 0.30 & 0.05 & 0.35 \\
\hline
\end{tabular}

TABLE 2: Rock mass classification for the Guoduo dam foundation.

\begin{tabular}{|c|c|c|c|c|}
\hline Class & Rock mass structure & Rock mass description & Weathering & $\begin{array}{c}\text { Uniaxial } \\
\text { compression } \\
\text { strength }(\mathrm{MPa}) \\
\end{array}$ \\
\hline $\begin{array}{l}\text { III1A } \\
\text { III2A }\end{array}$ & $\begin{array}{l}\text { Thick layered structure } \\
\text { surface, steep dip structural } \\
\text { plane in abutment }\end{array}$ & $\begin{array}{l}\text { Hard rock, intact and massive, high } \\
\text { strength, antislip deformation } \\
\text { resistance controlled by the structural } \\
\text { planes. Weak rock mass is affected by } \\
\text { weathering and unloading; local rock } \\
\text { mass is poor }\end{array}$ & $\begin{array}{c}\text { Fresh to slightly } \\
\text { Weak }\end{array}$ & $\mathrm{Rb}>60 \mathrm{MPa}$ \\
\hline $\begin{array}{l}\text { IV1B } \\
\text { IV2B }\end{array}$ & $\begin{array}{l}\text { Interbedded or lamellar } \\
\text { structure; some structures } \\
\text { may cause dam foundation } \\
\text { and abutment instability }\end{array}$ & $\begin{array}{l}\text { Rock masses are relatively poor intact, } \\
\text { antislip deformation resistance } \\
\text { controlled by the structural planes and } \\
\text { rock mass of chimeric ability. The rock } \\
\text { mass cannot be directly used as dam } \\
\text { foundation and must be effectively } \\
\text { reinforced before used locally }\end{array}$ & $\begin{array}{c}\text { Fresh to slightly } \\
\text { Weak }\end{array}$ & $\mathrm{Rb}=30-60 \mathrm{Mpa}$ \\
\hline IVC & $\begin{array}{l}\text { Interbedded or lamellar } \\
\text { structure; some structures } \\
\text { obviously cause dam } \\
\text { foundation and abutment } \\
\text { instability }\end{array}$ & $\begin{array}{l}\text { Soft rock, rock intact, low strength, } \\
\text { antislip, and deformation resistance } \\
\text { performance are poor. The rock mass } \\
\text { cannot be used as dam foundation and } \\
\text { is excavated }\end{array}$ & Fresh to slightly & $\mathrm{Rb}<30 \mathrm{MPa}$ \\
\hline
\end{tabular}

where $I_{1}$ is the first invariant stress, $J_{2}$ is the second invariant stress, and $\alpha$ and $H$ are material constants, which can be determined according to

$$
\begin{aligned}
& \alpha=\frac{3 \operatorname{tg} \varphi}{\sqrt{9+12 \operatorname{tg}^{2} \varphi}}, \\
& H=\frac{3 c}{\sqrt{9+12 \operatorname{tg}^{2} \varphi}},
\end{aligned}
$$

where $c$ is cohesion and $\varphi$ is friction angle. Equations (1) and (2) also show that the D-P criterion and the M-C (i.e., Mohr-Coulomb) criterion have the same expressions for the plane strain problem. In the $\pi$ plane, the $\mathrm{D}-\mathrm{P}$ circle has the intermediate values of the circumscribing circle and the inscribed circle to the $\mathrm{M}-\mathrm{C}$ hexagon. Nonlinear elastoplastic finite element analysis can determine conditions such as plastic yield, subcritical fracture, and unstable extension and plot the unbalanced force and point safety factor contours for the upstream and downstream surfaces of the dam.

The stress adjustment process in the nonlinear finite element analysis with the D-P criterion can be listed as follows: stress and strain at the initial point are set to be $\sigma_{0}$ and $\varepsilon_{0}$ and $f\left(\sigma_{0}\right) \leq 0$. For a given load step or iteration, the strain increment $\Delta \boldsymbol{\varepsilon}$ at the point can be obtained by the displacement method and the stress can be correspondingly calculated using

$$
\sigma_{1}=\sigma_{i j}^{1}=\mathbf{D}:\left(\boldsymbol{\varepsilon}_{0}+\Delta \boldsymbol{\varepsilon}\right)
$$

where $\mathbf{D}$ is the elasticity tensor. If $f\left(\sigma_{1}\right)>0$, then the stress needs adjustment. If the plastic strain increment of the loading step or iteration is $\Delta \boldsymbol{\varepsilon}^{p}$, then the stress after adjusting can be written using

$$
\boldsymbol{\sigma}=\sigma_{i j}=\mathbf{D}:\left(\boldsymbol{\varepsilon}_{0}+\Delta \boldsymbol{\varepsilon}-\Delta \boldsymbol{\varepsilon}^{p}\right)=\boldsymbol{\sigma}_{1}-\mathbf{D}: \Delta \boldsymbol{\varepsilon}^{p} .
$$




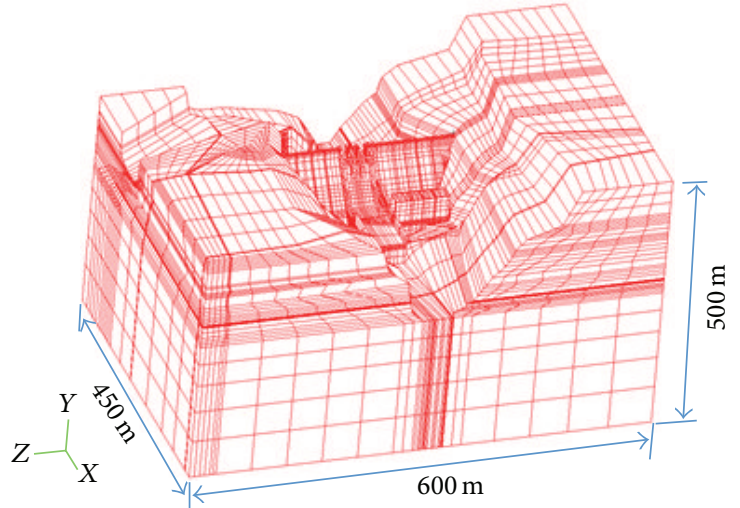

(a) Overall 3D mesh

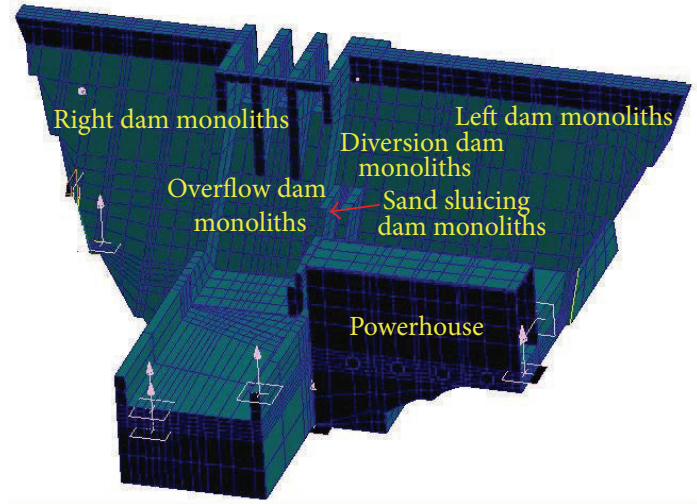

(b) Dam downstream

FIGURE 2: Schematic mesh model of Guoduo gravity dam.

Figure 2 depicts the numerical model for the Guoduo gravity dam, which consists of the whole dam structure, and its foundations including faults $\mathrm{f} 2-\mathrm{f} 7$, and the main weak zones of the right slope and rock mass types III2A, III1A, IV2B, and IV1B; see Table 2. In dynamic analysis, the concrete dynamic strength and elastic modulus of the standard value are increased to $30 \%$ compared with their static standard value and dynamic tensile strength of concrete is $10 \%$ of the dynamic compressive strength. The $3 \mathrm{D}$ finite element mesh includes a large proportion representing abutments and is of size $450 \mathrm{~m} \times 600 \mathrm{~m} \times 500 \mathrm{~m}$ (length $\times$ width $\times$ height). The total number of elements is 25805,10181 of which represent the dam body. follows:

In this study, the main loadings considered were as

(1) self-weight load;

(2) upstream, downstream water pressure, the normal upstream water being at EL $3418 \mathrm{~m}$, corresponding to the downstream tail water at EL $3360.91 \mathrm{~m}$;

(3) sediment pressure, silt elevation of $3378.38 \mathrm{~m}$, density, $\gamma_{n}$, being $8 \mathrm{kN} / \mathrm{m}^{3}$, internal friction angle, $\phi_{n}$, being $10^{\circ}$. The sediment pressure was calculated by

$$
p_{n}=\gamma_{n} h_{n} \tan ^{2}\left(45^{\circ}-\frac{\phi_{n}}{2}\right)
$$

(4) the seismic loading horizontal design earthquake acceleration that was $0.09 \mathrm{~g}$. The vertical design earthquake acceleration was $2 / 3$ of the horizontal design acceleration. Standard spectra were used, respectively, to generate the three directions of the artificial seismic waves (Figure 3);

(5) the earthquake dynamic water pressure that is calculated using the Westergaard dynamic water pressure formula [35]. Consider

$$
p=\frac{7}{8} \rho \sqrt{H(H-Z)} \ddot{v}_{g}
$$

where $p$ is the dynamic water pressure on some point of the dam surface, $\rho$ represents water density, $H$ is the reservoir water depth, $Z$ is the height of the point above the damfoundation interface, and $\ddot{v}_{g}$ is the acceleration of the dam node.

According to the specifications for seismic design of hydraulic structures (DL5073-2000) [35], in addition to using the dynamic response spectrum that the design institute provides, the time history analysis method should select, for dynamic analysis, a set of observed seismic waves which are similar to the likely site conditions. This study selected the artificial seismic wave inverted by the site spectrum. The response spectrum values derived using formulae (7), spectral curve, are shown in Figure 3, where $\beta_{\max }=2.25$, features period $T_{g}=0.25 \mathrm{~s}$. The inversed seismic waves and the response spectrum are shown in Figure 3. Consider

$$
\begin{aligned}
& \beta(T) \\
& = \begin{cases}1 & T=0 \\
1+\left(\beta_{\max }-1\right) \frac{T}{0.1} & 0 \leq T \leq 0.1 \mathrm{~s} \\
\beta_{\max } & 0.1 \mathrm{~s} \leq T \leq T_{g} \\
\max \left[0.2 \beta_{\max }, \beta_{\max }\left(\frac{T_{g}}{T}\right)^{0.9}\right] & T_{g} \leq T \leq 3 \mathrm{~s} .\end{cases}
\end{aligned}
$$

2.3. Analysis Cases. The 3D finite element nonlinear dynamic analysis program for the Guoduo gravity dam was executed as follows: (1) for different load cases, checking stresses and deformations of the dam; (2) study of the cracking and failure processes of the dam under normal static and dynamic conditions; (3) evaluation of dam and foundation overall seismic fortification. The numerical results obtained from analysis cases no. 1 to no. 7 are shown in Table 3 .

\section{Elastic Analysis under Static and Dynamic Loading}

In this section, the linear elastic $3 \mathrm{D}$ analysis results for the Guoduo gravity dam for Cases 1 and 2 are discussed. Typical dam monolith analyses include the right hand side dam 

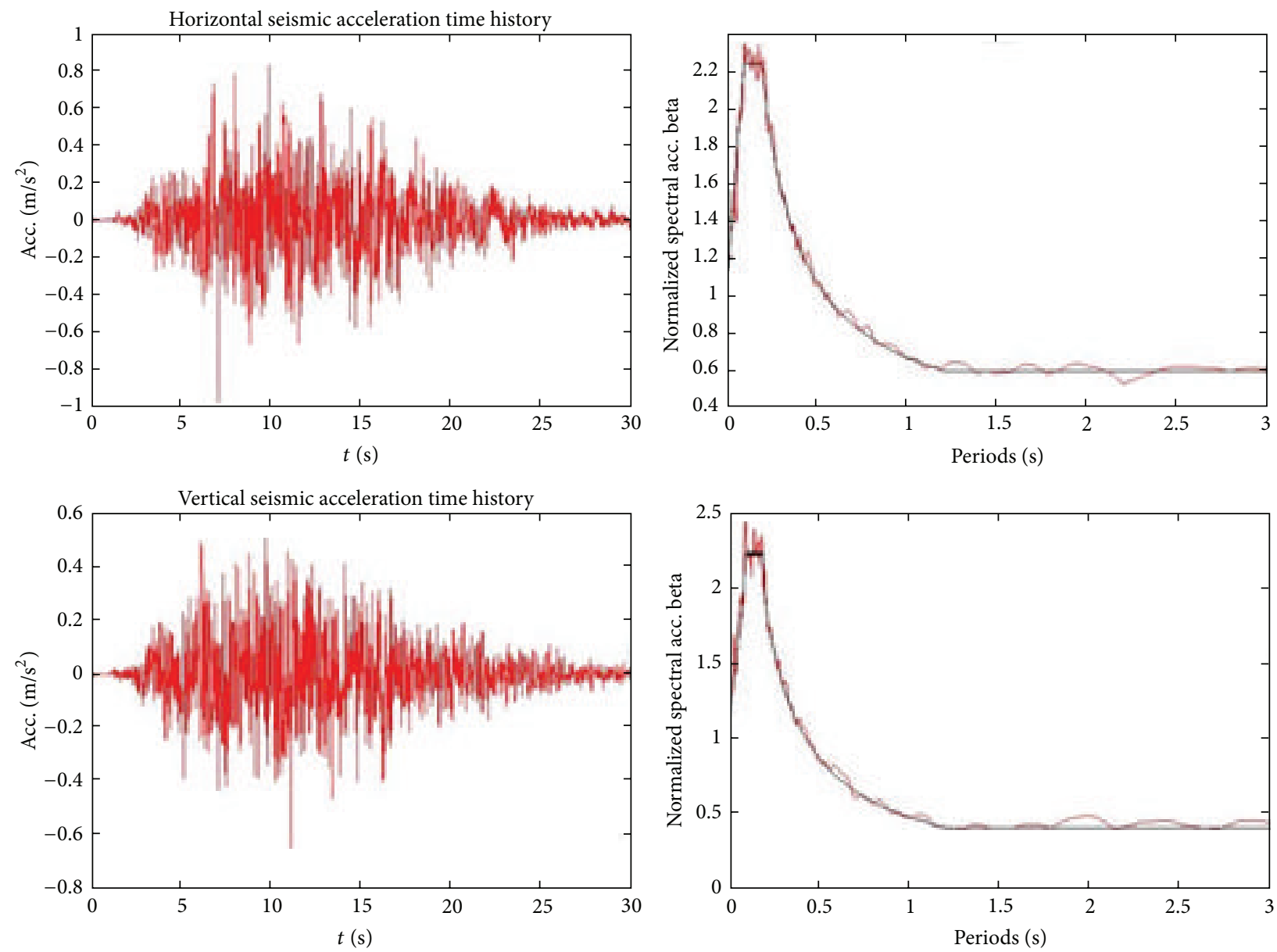

The standard spectrum
- The artificial seismic response spectrum

FiguRE 3: Inversed seismic waves and the response spectrum.

TABLE 3: Summary of the analysis cases studied in the 3D finite element modelling.

\begin{tabular}{|c|c|}
\hline $\begin{array}{l}\text { Analysis case } \\
\text { number }\end{array}$ & Loading combination \\
\hline 1 & Static loadings, self-weight + upstream normal water loading + silt load + downstream water load (3D linear elastic) \\
\hline 2 & $\begin{array}{l}\text { Static and dynamic loadings, Case } 1+\text { design seismic load, horizontal seismic acceleration, } 0.09 \mathrm{~g} \text { (3D linear elastic, } \\
\text { response analysis) }\end{array}$ \\
\hline 3 & Static loadings, self-weight + upstream normal water loading + silt load + downstream water load (3D nonlinear) \\
\hline 4 & $\begin{array}{l}\text { Static and dynamic loadings, Case } 3+\text { design seismic load, horizontal seismic acceleration, } 0.09 \mathrm{~g} \text { (3D linear elastic, time } \\
\text { history analysis) }\end{array}$ \\
\hline 5 & $\begin{array}{l}\text { Static and dynamic loadings, Case } 3+\text { design seismic load, horizontal seismic acceleration, } 0.18 \mathrm{~g} \text { ( } 3 \mathrm{D} \text { linear elastic, time } \\
\text { history analysis) }\end{array}$ \\
\hline 6 & $\begin{array}{l}\text { Static and dynamic loadings, Case } 3+\text { design seismic load, horizontal seismic acceleration, } 0.27 \mathrm{~g} \text { (3D linear elastic, time } \\
\text { history analysis) }\end{array}$ \\
\hline 7 & $\begin{array}{l}\text { Static and dynamic loadings, Case } 3+\text { design seismic load, horizontal seismic acceleration, } 0.36 \mathrm{~g} \text { (3D linear elastic, time } \\
\text { history analysis) }\end{array}$ \\
\hline
\end{tabular}




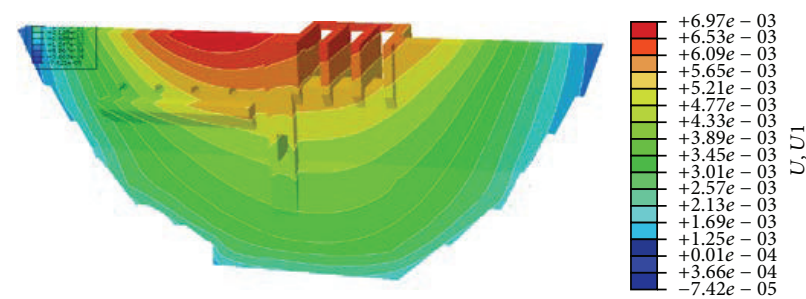

(a) Upstream displacement distribution in river direction

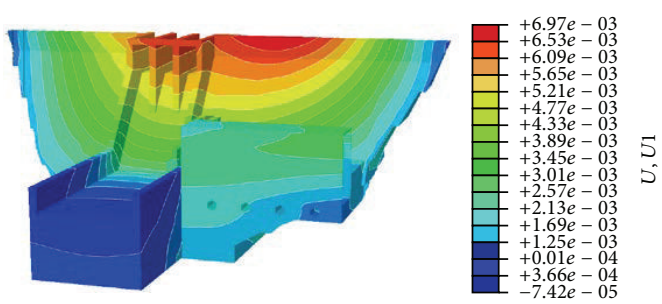

(b) Downstream displacement distribution in river direction

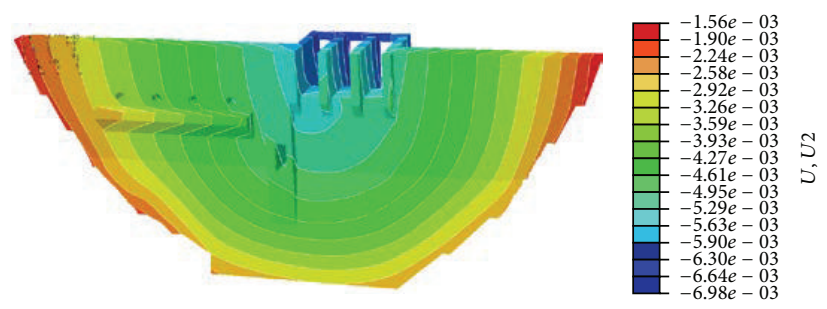

(c) Upstream displacement distribution in vertical riverbed direction

FIGURE 4: Dam displacement contour in various directions under analysis Case 1 (unit: m).

monoliths, the overflow dam monoliths, the diversion dam monoliths, and the left hand side dam monoliths. Four typical profiles are $\# 0+65.4$ and $\# 00+97.00$ within the diversion dam monoliths, $\# 0+127.00$ within the overflow dam monoliths, and $\# 0+159.00$, a right hand side dam monolith.

3.1. Dam Deformation Analysis. Table 4 shows three-dimensional stress and displacement results for the five typical dam monoliths. The displacement distribution of the upstream and downstream surfaces is illustrated in Figure 4. The stress and displacement results for all dam profiles for analysis Cases 1 and 2 are shown in Table 5. For analysis Cases 1 and 2 the symmetry of the displacement distributions is good, which shows that the dam abutments and riverbed foundation possess good overall stiffness. The maximum upstream face and downstream face displacements (along the river direction) of the dam (Figure 4) are $0.697 \mathrm{~cm}$ and $1.707 \mathrm{~cm}$, respectively, at the \#0+97.00 profile for the diversion dam monolith. The maximum displacements (settlement direction) were $0.679 \mathrm{~cm}$ and $0.915 \mathrm{~cm}$, respectively, at the $\# 0+127.00$ profile of the overflow dam monolith. Threedimensional analysis results show that the distribution of displacement deformations for typical sections is reasonable, consistent with the characteristics of gravity dam displacement distribution in general, and the settlements are uniform.

3.2. Dam Stress Analysis. For challenging problems in dam design, it is vitally important to investigate clearly the stress distributions in both the dam and its foundation, especially in the tensile zone upstream at the heel of the gravity dam, close to the downstream toe of the dam, and at the dam-foundation contact surface. For analysis Case 1, stress characteristic values for the typical dam monoliths are illustrated in Tables 4 and 5 .
For all typical dam monoliths, under analysis Case 1, the maximum principal stress and compression stress level were about $2.308 \mathrm{MPa}$ and $3.232 \mathrm{MPa}$ at the left hand side dam monolith and the toe of diversion dam monoliths, respectively. For all typical dam profiles, under analysis Cases 1 and 2, the maximum principal tensile stresses were about $0.4 \mathrm{MPa}(\# 0+159.00)$ and $2.0 \mathrm{MPa}(\# 0+65.40)$, respectively. The maximum compressive stresses are about $1.4 \mathrm{MPa}(\# 0+$ $159.00)$ and $1.6 \mathrm{MPa}(\#+159.00)$, respectively. Based on the numerical analysis, the tension and compression stress distribution is homogeneous, and the stress levels of the main parts, such as dam heel and dam toe, are within satisfactory limits. The stress distribution, therefore, can be considered safe for dam operation under normal water loading. A local tensile stress occurs at the upper junction of dam and foundation, the outlets of the diversion dam monoliths, and the parts in bending of the sand sluicing, diversion dam monoliths. Attention must, therefore, be paid, to the applied prestressed or other reinforcement designs of these sections so as to provide the capability of sustaining those stresses.

\section{Nonlinear Analysis under Static and Dynamic Loading}

4.1. Dam Deformation Analysis. For analysis Case 4, Table 5 shows the main stress and the deformation characteristic values for the typical dam profiles. The three-dimensional integral displacement distribution is illustrated in Figure 5. Comparing these results and those for static loading (Tables 4 and 5), the main conclusions are as follows.

(1) The maximum displacement (along the river direction) (Figure 5) was $2.36 \mathrm{~cm}$, at \#0 +65.40 profile of the diversion dam monolith. The maximum displacement (settlement direction) was $1.10 \mathrm{~cm}$, at 


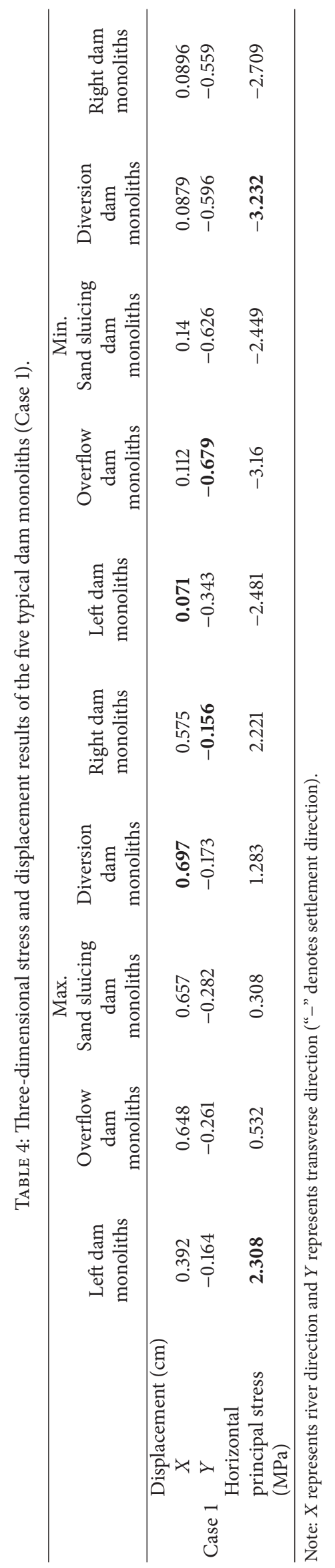




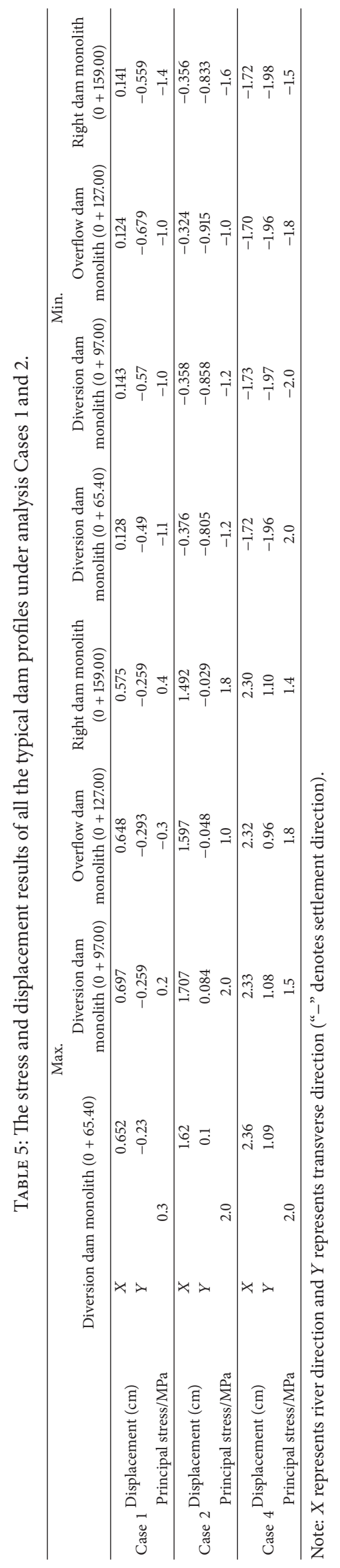




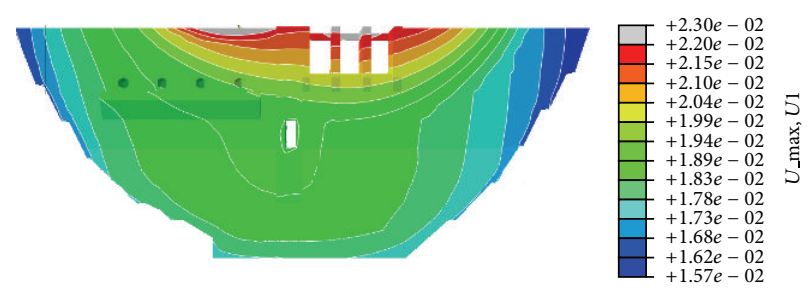

(a) Upstream displacement distribution in river direction

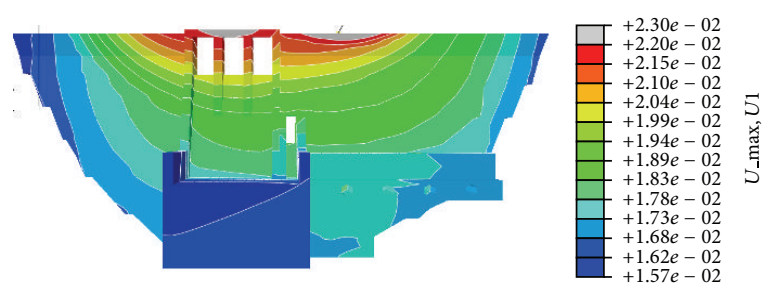

(b) Downstream displacement distribution in river direction

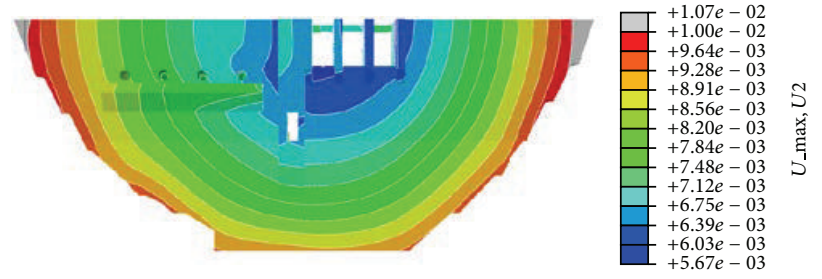

(c) Upstream displacement distribution in vertical riverbed direction

FIGURE 5: Dam displacement contour in various directions under analysis Case 4 (unit: $\mathrm{m}$ ).

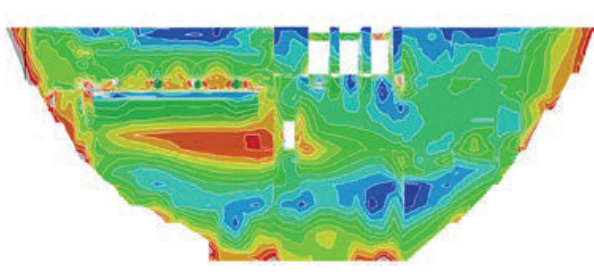

(a) Max. principal stress of upstream surface
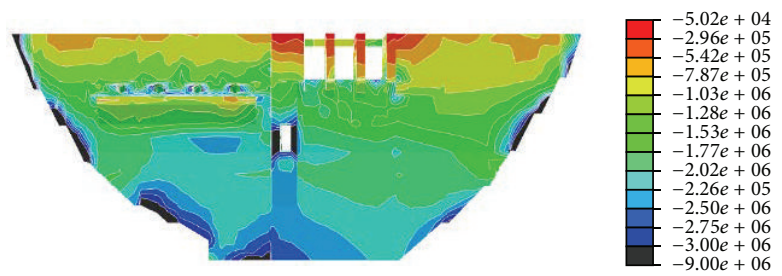

(c) Min. principal stress of upstream surface

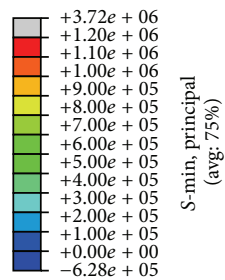

FIGURE 6: Principal stress contour of dam upstream/downstream under analysis Case 4 (unit: Pa).

$\# 0+159.00$ profile of the overflow monoliths. The three-dimensional analysis results show that the displacement deformation distribution of the typical sections is reasonable, consistent with the characteristics of gravity dam displacements distribution in general, and the settlements are uniform.

(2) The maximum displacements along the river and in the settlement directions for analysis Case 2 increased by 1.4 and 1.3 times, respectively, when compared with the results of the linear elastic static working condition (analysis Case 1). The maximum displacements along the river and settlement direction under analysis Case 4 increased by about 2 and 1.1 times, respectively, compared with the results for analysis Case 1.
4.2. Dam Stress Analysis. For analysis Case 4, the 3D stress distribution for the Guoduo dam is shown in Figure 6. Figure 7 illustrates the max. and min. principal stresses for typical profiles. The characteristic stress values within the typical monoliths are shown in Table 5.

The overall upstream surface sustained the compression pressure, the maximum tensile principal stress level in the typical dam monoliths being about $1.5 \mathrm{MPa}$ (the left hand side dam monolith downstream side), and the maximum compressive stress is about $3.0 \mathrm{MPa}$ (the wall corner of the sand sluicing dam monolith). For all the typical dam profiles, for analysis Cases 4, the maximum principal stresses are about $2 \mathrm{MPa}(\# 0+159.00)$. The maximum compressive stresses are about $2 \mathrm{MPa}(\# 0+65.40)$.

Based on the numerical analysis Case 4, the tension and compression stress distributions are similar to those 


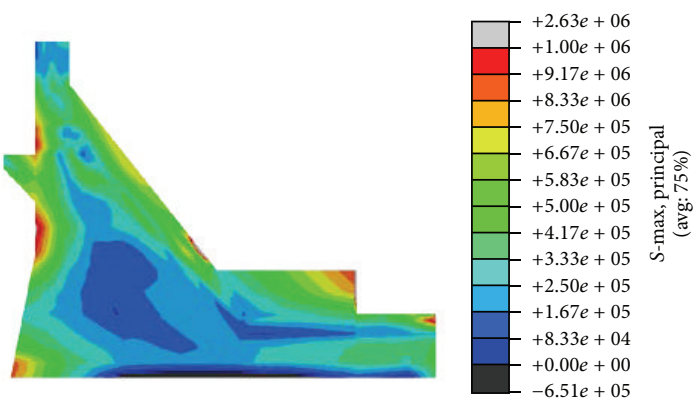

(a) Max. principal stress of $0+65.40$ cross-section
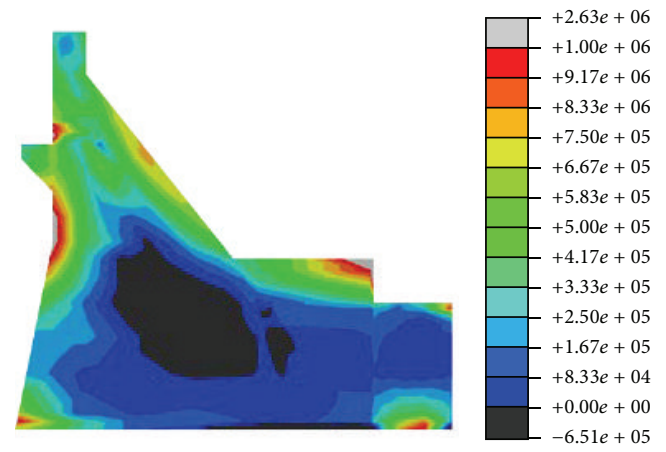

(c) Max. principal stress of $0+97.00$ cross-section
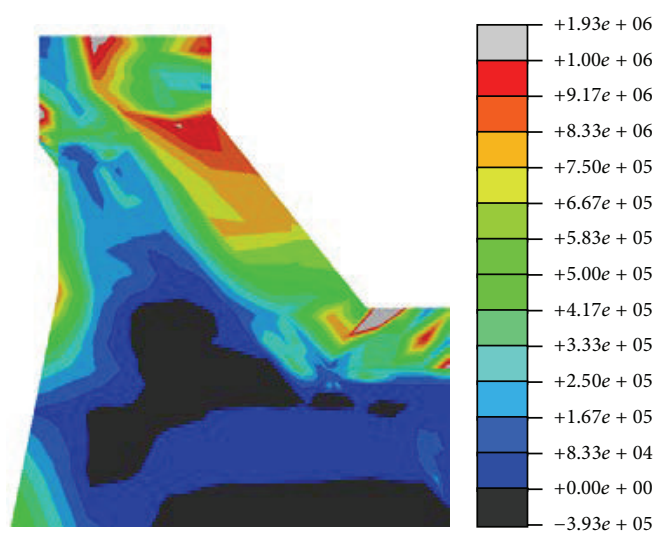

(e) Max. principal stress of $0+97.00$ cross-section
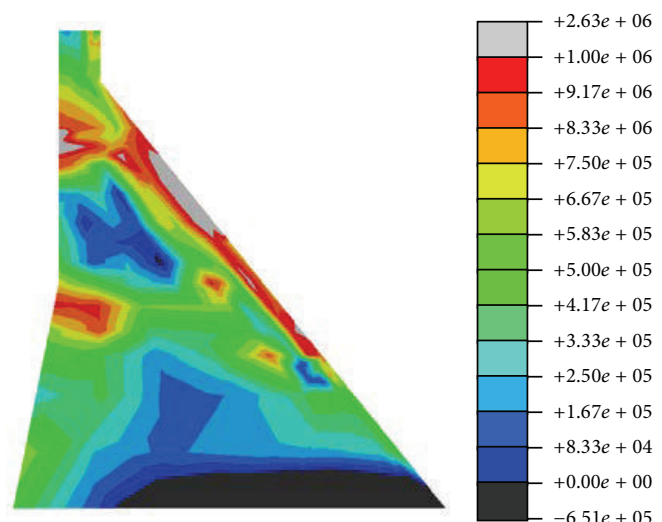

(g) Max. principal stress of $0+159.00$ cross-section
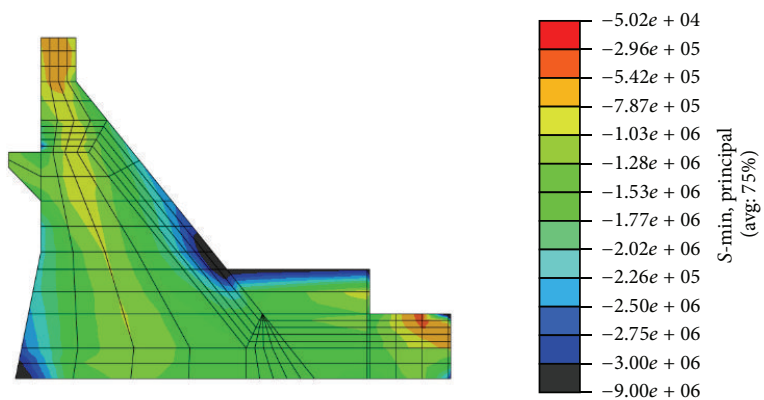

(b) Min. principal stress of $0+65.40$ cross-section
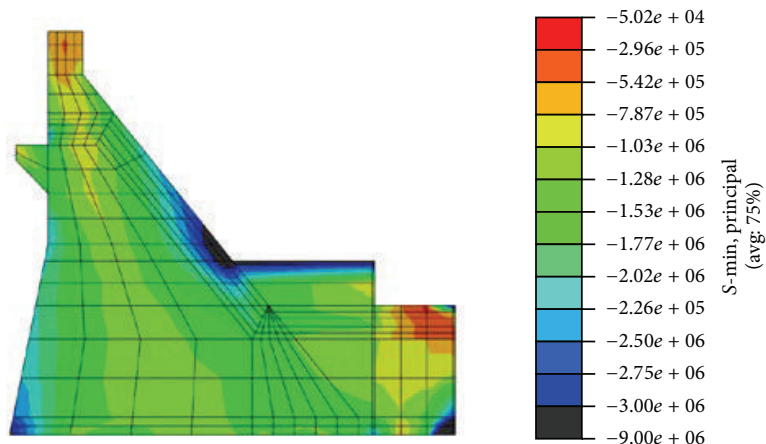

(d) Min. principal stress of $0+97.00$ cross-section
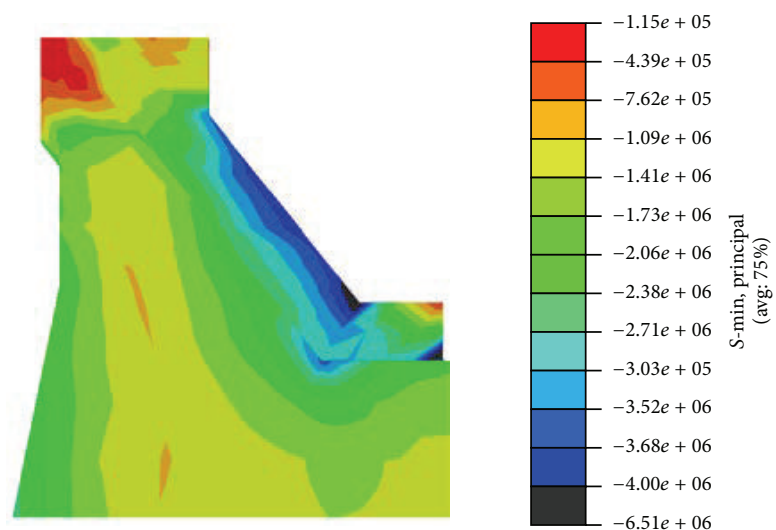

(f) Min. principal stress of $0+97.00$ cross-section
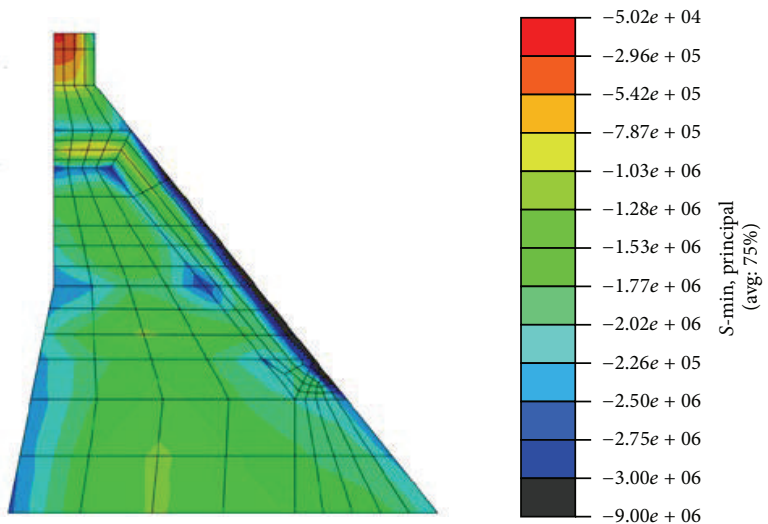

(h) Min. principal stress of $0+159.00$ cross-section

FIgURe 7: Principal stress of typical section under analysis Case 4 (unit: Pa). 
TABLE 6: The maximum equivalent plastic strain of the typical dam monoliths. (Analysis Cases 4-7).

\begin{tabular}{|c|c|c|c|c|c|}
\hline & & $\begin{array}{c}\text { Diversion dam } \\
\text { monoliths }(0+ \\
65.40)\end{array}$ & $\begin{array}{l}\text { Diversion dam } \\
\text { monoliths }(0+ \\
97.00)\end{array}$ & $\begin{array}{l}\text { Overflow dam } \\
\text { monoliths }(0+ \\
127.00)\end{array}$ & $\begin{array}{c}\text { The right dam } \\
\text { monoliths }(0+ \\
159.00)\end{array}$ \\
\hline Case 4 & Working statues & \multicolumn{4}{|c|}{ Elastic } \\
\hline \multirow[t]{2}{*}{ Case 5} & $\begin{array}{l}\text { The maximum } \\
\text { equivalent plastic } \\
\text { strain }\end{array}$ & $2.0 e-4$ & $2.0 e-4$ & $5.833 e-5$ & $5.000 e-5$ \\
\hline & Location & \multicolumn{4}{|c|}{ Downstream surface } \\
\hline \multirow[t]{2}{*}{ Case 6} & $\begin{array}{l}\text { The maximum } \\
\text { plastic strain }\end{array}$ & $5.4 e-4$ & $3.625 e-4$ & $3.379 e-4$ & $2.422 e-4$ \\
\hline & Location & \multicolumn{4}{|c|}{ Downstream surface } \\
\hline \multirow[t]{2}{*}{ Case 7} & $\begin{array}{l}\text { The maximum } \\
\text { plastic strain }\end{array}$ & $1.001 e-3$ & $9.834 e-4$ & $1.180 e-3$ & $8.169 e-3$ \\
\hline & Location & \multicolumn{4}{|c|}{ Downstream surface } \\
\hline
\end{tabular}

$t$ of Case 2 (Section 3.2). A local tensile stress occurs at the upper junction of dam and foundation, the outlets of the diversion dam monoliths, and the parts in bending of the sand sluicing, diversion dam monoliths. Attention must, therefore, be paid to the applied prestressed or other reinforcement designs of these sections so as to provide the capability of sustaining those stresses. Compared with analysis Case 1, the maximum numerical analysis derived principal stress increased significantly for analysis Cases 2 and 4 (Table 5). The maximum principal stress for Case 4 is four times that for Case 1. Compared with Case 1, the maximum compression stress increased by 13 percent for Case 2 (Table 5) and by $40 \%$ for Case 4.

4.3. Seismic Safety Analysis. This section describes an analysis of the ultimate seismic capacity of the dam using the "overload safety factor method," based on nonlinear finite element analysis. For different analysis cases (Table 3) the instability mechanism and seismic fortification of the dam-foundation system were simulated under overload conditions. Detailed dam failure and the plastic zone locations for the different analysis cases are illustrated in Table 6 . The yielding process of the upstream and downstream surfaces is shown in Figure 8.

The numerical results show the following.

(1) For analysis Case 4, the dam and foundation remained within the elastic range.

(2) For analysis Case 5, the seismic horizontal acceleration was more than twice as big with yielding appearing in the diversion pipe, flushing hole, pier and beam junctions, pier wall, and the top of the plan. The equivalent plastic strain value was $4.0 e-3$, located in the pier wall near the flushing hole (Figures 8(a) and $8(\mathrm{~b})$ ). Yielded zones also occurred in some parts of dam abutments, but the equivalent plastic strain value is small.

(3) For analysis Cases 5 and 6, the seismic horizontal acceleration was more than twice and three times, respectively. The maximum plastic strain values were $7.0 e-3$ and $1.0 e-2$, respectively. Dam abutments began to show large yielded zones (Figures $8(\mathrm{c})-8(\mathrm{f})$ ).

(4) For each overloading step increment above seismic horizontal acceleration (hereafter $g_{0}$ means normal seismic horizontal acceleration) those elements yielding were identified and safety factors computed. The safety evaluation methods for high arch dams consist mainly of (1) overloading, (2) strength reduction, and (3) comprehensive tests. In this study, overload safety factor method assumes that the mechanical foundation rock mass parameters remain constant while the seismic horizontal acceleration is increased until the dam and the foundation fail. The overall stability safety factors are defined as follows: $K 1$ represents the dam safety factor against initial cracking; a crack initiated at $K 1 g_{0}$. K2 represents the safety factor against structural nonlinear behaviour. In the nonlinear phase, the downstream dam surface shows a large yield zone during this nonlinear behaviour. The cracks in the dam propagate quickly and multiple cracks coalesce. $K 3$ represents the maximum seismic fortification safety factor for the dam-foundation system. At $K 3 g_{0}$, the dam foundation fails and dam capacity is lost. Based on numerical analysis, as increase of seismic horizontal acceleration occurs, the equivalent plastic strain increases. When acceleration reached $0.27 \mathrm{~g}$, about $30 \%$ of the dam reached the yield stage. Thus, $K 1=1.5, K 2=2 \sim 3$, and $K 3=3 \sim 4$.

(5) Based on numerical analysis, under overloading (dynamic loading), the yielded zones appeared at the stress concentration areas, such as the dam heel, the dam joint face, and bank slope surfaces of the bank upstream and downstream. A large yielded zone appeared in the back tube and planthouse (Figures $8(\mathrm{~g})$ and $8(\mathrm{~h}))$. It is suggested that these yield zones should be reinforced, to improve the overall seismic safety performance of the Guoduo gravity dam. 


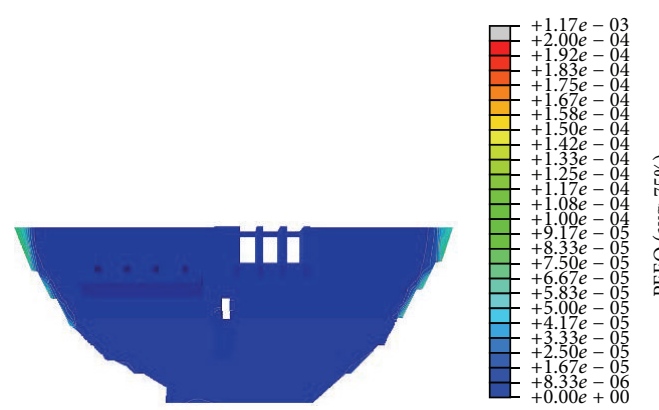

(a) Upstream, under analysis Case 4
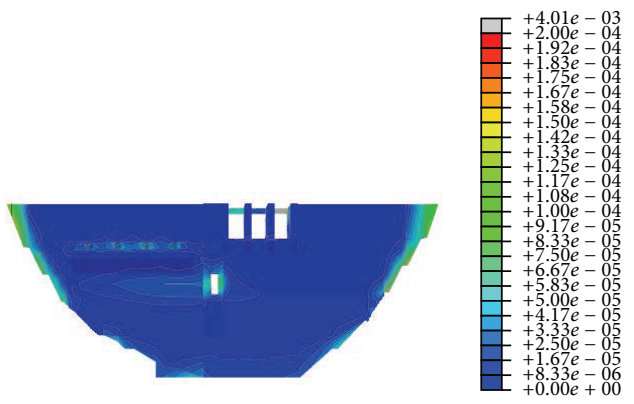

(c) Upstream, under analysis Case 5

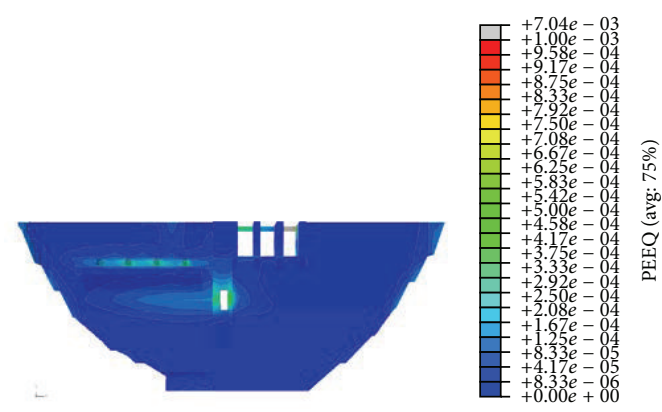

(e) Upstream, under analysis Case 6

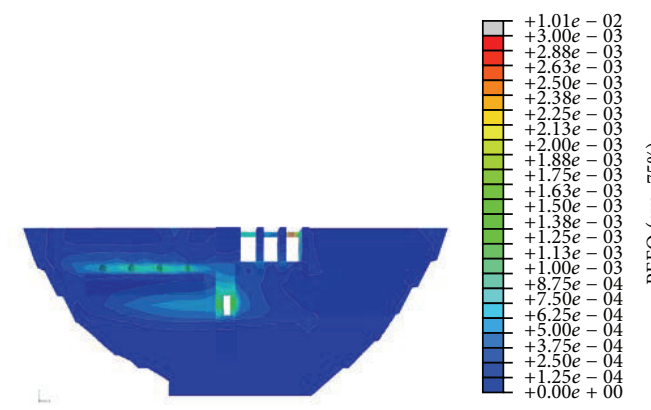

(g) Upstream, under analysis Case 7

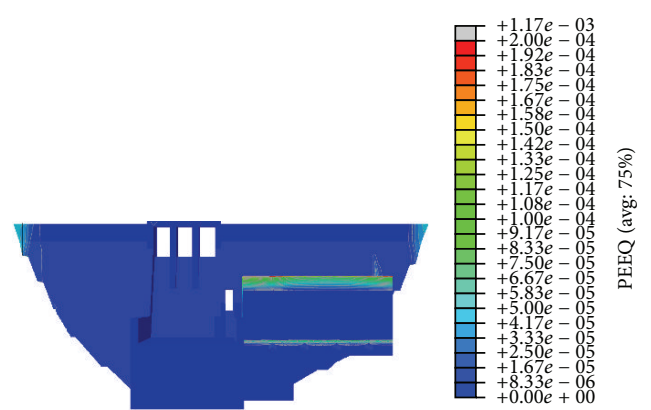

(b) Downstream, under analysis Case 4

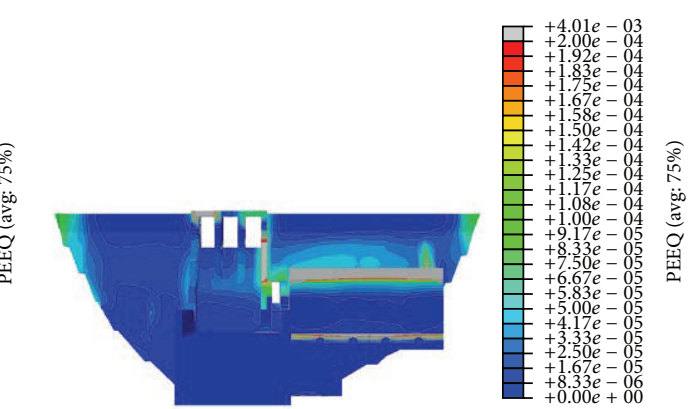

(d) Downstream, under analysis Case 5

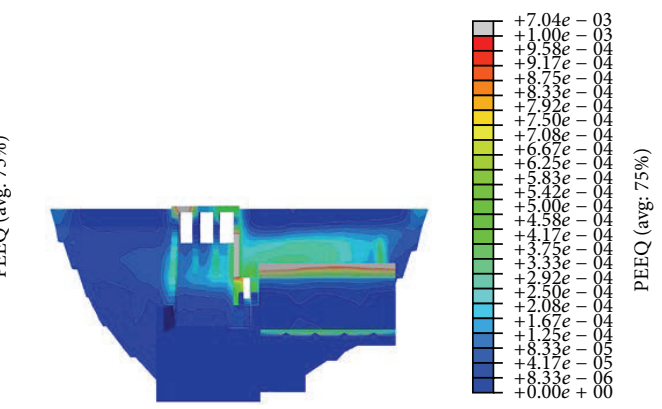

(f) Downstream, under analysis Case 6

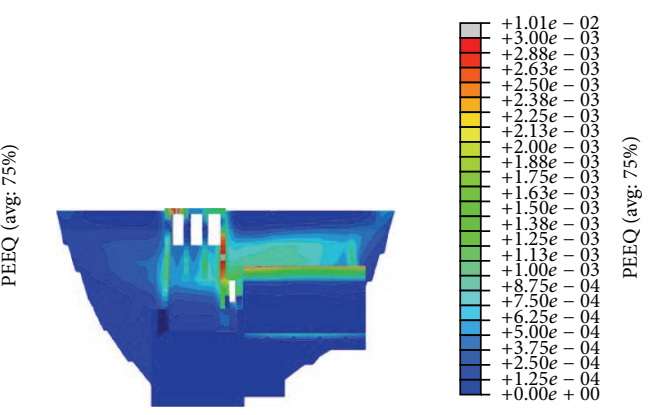

(h) Downstream, under analysis Case 7

FIGURE 8: Dam upstream/downstream yield zone under various analysis cases.

\section{Conclusions}

This study analyzed and understood the seismic performance of the Guoduo dam. The geological conditions affecting seismic performance of the Guoduo dam are first discussed below. The deformation, stress, cracking risk, and overall seismic stability of the Guoduo were analyzed using a 3D finite element method, under various dynamic and static loadings and a description is given below. The following conclusions can be drawn.

For analysis Cases 1,2, and 4, the symmetry of the displacement distributions is good, which shows that the dam abutments and riverbed foundation have good overall stiffness. The maximum displacements (along the river direction) of the dam were $0.697 \mathrm{~cm}, 1.707 \mathrm{~cm}$, and $2.36 \mathrm{~cm}$ at $\# 0+97.00$ profile of diversion dam monolith, respectively. 
The maximum principal tension stresses at various analyses 1,2 , and 4 were about $0.4 \mathrm{MPa}(\# 0+159), 2.0 \mathrm{MPa}(\# 0+$ $65.4)$, and $2.0 \mathrm{MPa}(\# 0+159)$, respectively. The maximum compression stresses at various analyses 1,2 , and 4 were $-1.4 \mathrm{MPa}(\# 0+159),-1.6 \mathrm{MPa}(\# 0+159)$, and $-2.0 \mathrm{MPa}$ $(\# 0+159)$, respectively. Based on the numerical analysis, the stress distribution is safe for dam operation under normal water loading and seismic loading.

Based on the numerical analysis, the tension and compression stresses distribution is homogeneous, and the stress levels of the key components, such as dam heel and dam toe, are within safe limits for dam operation under normal water loading. A local tensile stress occurs at the upper dam foundation junction, the outlets of the diversion dam monoliths, and the parts in bending of the sand sluicing, diversion dam monoliths. Attention, therefore, must be paid to the reinforcement design for these sections to enhance the capability of sustaining tensile stresses. A reinforcement design should control the local cracking risk by selecting the appropriate concrete materials, using small diameter reinforcing bars, and improving temperature control measures for pouring mass concrete during construction.

The shape of the dam profile has a significant effect on the dynamic response of the dam. Numerical results show that highly stressed areas easily occur where there is a sudden change of geometry. In addition, after considering the interaction between the planthouse and diversion dam monoliths, although the planthouse can enhance the overall stiffness and stability of the dam, the high stiffness low down on the dam easily causes stress concentration at the dam downstream surface. This situation is not helpful to the safety of the dam body under strong earthquake action.

Based on numerical simulation, by employing the "overload safety factor method," the overall seismic fortification factors are as follows: $K 1=1.5, K 2=2 \sim 3$, and $K 3=3 \sim 4$.

\section{Conflict of Interests}

The authors declare that there is no conflict of interests regarding the publication of this paper.

\section{Acknowledgments}

This research work was supported by National Natural Science Foundation of China (nos. 11272178 and 51339003), National Basic Research Program of China (973 Program) Grant no. 2011CB013503, and Tsinghua University Initiative Scientific Research Program. The authors are very grateful to Guiyang Hydroelectric Investigation and Design Institute for supporting this study.

\section{References}

[1] L. M. Zhang, "Settlement patterns of soft soil foundations under embankments," Canadian Geotechnical Journal, vol. 36, no. 4, pp. 774-781, 1999.

[2] P. Lin, B. Huang, Q. Li, and R. Wang, "Hazard and seismic reinforcement analysis for typical large dams following the Wenchuan earthquake," Engineering Geology, 2014.
[3] P. Lin, T. H. Ma, Z. Z. Liang, C. A. Tang, and R. K. Wang, "Failure and overall stability analysis on high arch dam based on DFPA code," Engineering Failure Analysis, vol. 45, pp. 164-184, 2014.

[4] H. Tosun, I. Zorluer, A. Orhan, E. Seyrek, H. Savaş, and M. Türköz, "Seismic hazard and total risk analyses for large dams in Euphrates basin, Turkey," Engineering Geology, vol. 89, no. 1-2, pp. 155-170, 2007.

[5] P. Lin, W. Y. Zhou, and H. Y. Liu, "Experimental study on cracking, reinforcement and overall stability of the Xiaowan super-high arch dam," Rock Mechanics and Rock Engineering, 2014.

[6] ICOLD European Club, "Working group on guidelines for the seismic assessment of dams," 2004.

[7] US Army Corps of Engineers, Earthquake Design and Evaluation of Concrete Hydraulic Structure Engineer Manual, 2007.

[8] J. García-Mayordomo and J. M. Insua-Arévalo, "Seismic hazard assessment for the Itoiz dam site (Western Pyrenees, Spain)," Soil Dynamics and Earthquake Engineering, vol. 31, no. 7, pp. 1051-1063, 2011.

[9] H. Tosun, İ. Zorluer, A. Orhan, E. Seyrek, H. Savaş, and M. Türköz, "Seismic hazard and total risk analyses for large dams in Euphrates basin, Turkey," Engineering Geology, vol. 89, no. 1-2, pp. 155-170, 2007.

[10] T.-H. Yi, H.-N. Li, and M. Gu, "A new method for optimal selection of sensor location on a high-rise building using simplified finite element model," Structural Engineering and Mechanics, vol. 37, no. 6, pp. 671-684, 2011.

[11] B. Chen, Y. Z. Sun, Y. L. Li, and S. L. Zhao, "Control of seismic response of a building frame by using hybrid system with magnetorheological dampers and isolators," Advances in Structural Engineering, vol. 17, no. 8, pp. 1199-1215, 2014.

[12] T.-H. Yi, H.-N. Li, and M. Gu, "Optimal sensor placement for structural health monitoring based on multiple optimization strategies," The Structural Design of Tall and Special Buildings, vol. 20, no. 7, pp. 881-900, 2011.

[13] B. Chen, Y. L. Xu, and X. Zhao, "Integrated vibration control and health monitoring of building structures: a time-domain approach," Smart Structures and Systems, vol. 6, no. 7, pp. 811833, 2010.

[14] P. Lin, H. Y. Liu, Q. B. Li, and H. Hu, "Effects of outlets on cracking risk and integral stability of super-high arch dams," The Scientific World Journal, vol. 2014, Article ID 312827, 19 pages, 2014.

[15] Z. Z. Liang, C. A. Tang, H. X. Li, T. Xu, and Y. B. Zhang, "Numerical simulation of 3-d failure process in heterogeneous rocks," International Journal of Rock Mechanics and Mining Sciences, vol. 41, supplement 1, pp. 323-328, 2004.

[16] L. C. Li, C. A. Tang, W. C. Zhu, and Z. Z. Liang, "Numerical analysis of slope stability based on the gravity increase method," Computers and Geotechnics, vol. 36, no. 7, pp. 1246-1258, 2009.

[17] Z. Z. Liang, H. Xing, S. Y. Wang, D. J. Williams, and C. A. Tang, "A three-dimensional numerical investigation of the fracture of rock specimens containing a pre-existing surface flaw," Computers and Geotechnics, vol. 45, pp. 19-33, 2012.

[18] L. C. Li, C. A. Tang, G. Li, S. Y. Wang, Z. Z. Liang, and Y. B. Zhang, "Numerical simulation of 3D hydraulic fracturing based on an improved flow-stress-damage model and a parallel FEM technique," Rock Mechanics and Rock Engineering, vol. 45, no. 5, pp. 801-818, 2012.

[19] W. Pal, "Seismic cracking of concrete gravity dam," Journal of Structural Engineering ASCE, vol. 102, no. 9, pp. 1827-1844, 1976. 
[20] A. R. Ingraffea, "Case studies of simulation of fracture in concrete dams," Engineering Fracture Mechanics, vol. 35, no. 1-3, pp. 553-564, 1990.

[21] W. Guanglun, O. A. Pekau, Z. Chuhan, and W. Shaomin, "Seismic fracture analysis of concrete gravity dams based on nonlinear fracture mechanics," Engineering Fracture Mechanics, vol. 65, no. 1, pp. 67-87, 2000.

[22] M. L. Ayari and V. E. Saouma, "A fracture mechanics based seismic analysis of concrete gravity dams using discrete cracks," Engineering Fracture Mechanics, vol. 35, no. 1-3, pp. 587-598, 1990.

[23] N. Bouaanani and S. Renaud, "Effects of fluid-structure interaction modeling assumptions on seismic floor acceleration demands within gravity dams," Engineering Structures, vol. 67, pp. 1-18, 2014.

[24] Q. S. Li, Z. N. Li, G. Q. Li, J. F. Meng, and J. Tang, "Experimental and numerical seismic investigations of the Three Gorges dam," Engineering Structures, vol. 27, no. 4, pp. 501-513, 2005.

[25] M. Paggi, G. Ferro, and F. Braga, "A multiscale approach for the seismic analysis of concrete gravity dams," Computers and Structures, vol. 122, pp. 230-238, 2013.

[26] R. Tarinejad, R. Fatehi, and R. S. Harichandran, "Response of an arch dam to non-uniform excitation generated by a seismic wave scattering model," Soil Dynamics and Earthquake Engineering, vol. 52, pp. 40-54, 2013.

[27] M. Ghaemian and M. Sohrabi-Gilani, "Seismic responses of arch dams due to non-uniform ground motions," Scientia Iranica, vol. 19, no. 6, pp. 1431-1436, 2012.

[28] M. Akköse and E. Şimşek, "Non-linear seismic response of concrete gravity dams to near-fault ground motions including damwater-sediment-foundation interaction," Applied Mathematical Modelling, vol. 34, no. 11, pp. 3685-3700, 2010.

[29] S. Sica, L. Pagano, and A. Modaressi, "Influence of past loading history on the seismic response of earth dams," Computers and Geotechnics, vol. 35, no. 1, pp. 61-85, 2008.

[30] M. Sohrabi-Gilani and M. Ghaemian, "Spatial variation input effects on seismic response of arch dams," Scientia Iranica, vol. 19, no. 4, pp. 997-1004, 2012.

[31] V. Valamanesh, H. E. Estekanchi, A. Vafai, and M. Ghaemian, "Application of the endurance time method in seismic analysis of concrete gravity dams," Scientia Iranica, vol. 18, no. 3, pp. 326337, 2011.

[32] O. Omidi, S. Valliappan, and V. Lotfi, "Seismic cracking of concrete gravity dams by plastic-damage model using different damping mechanisms," Finite Elements in Analysis and Design, vol. 63, pp. 80-97, 2013.

[33] M. B. Ftima and P. Léger, "Seismic stability of cracked concrete dams using rigid block models," Computers and Structures, vol. 84, no. 28, pp. 1802-1814, 2006.

[34] ABAQUS, ABAQUS User's Manual, vol. 6.11, 2011.

[35] The Professional Standards Compilation Group of People's Republic of China (PSCG PRC), "Specification for seismic design of hydraulic structures," Tech. Rep. DL5073-2000, Electric Publish Press, Beijing: China, 2000. 

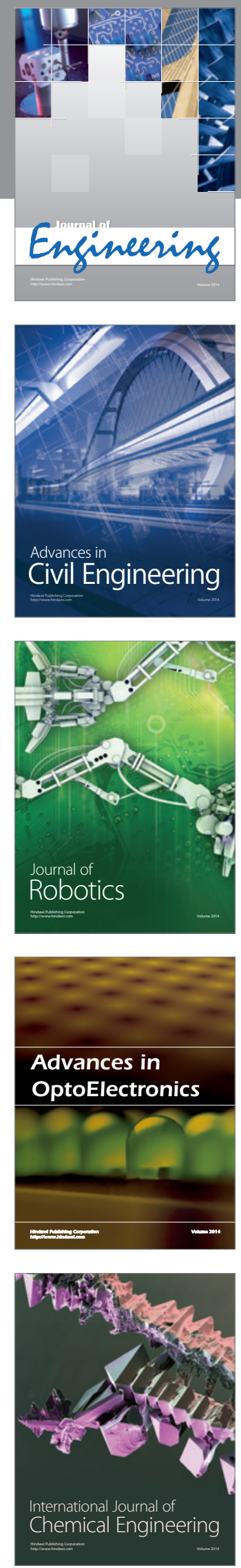

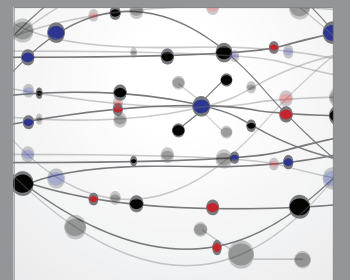

The Scientific World Journal
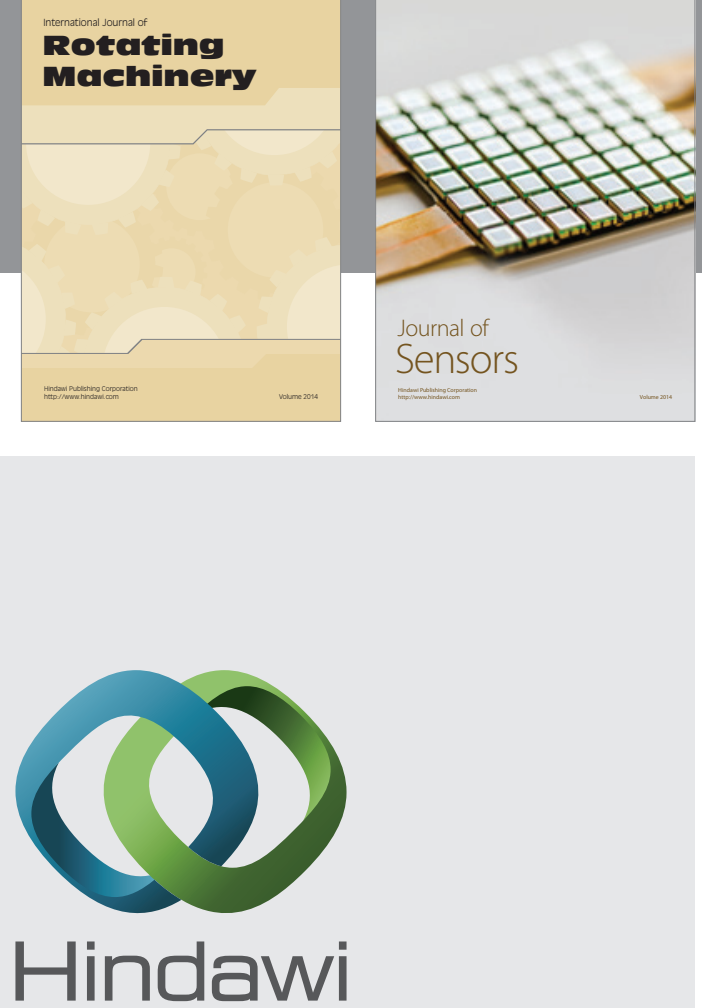

Submit your manuscripts at http://www.hindawi.com
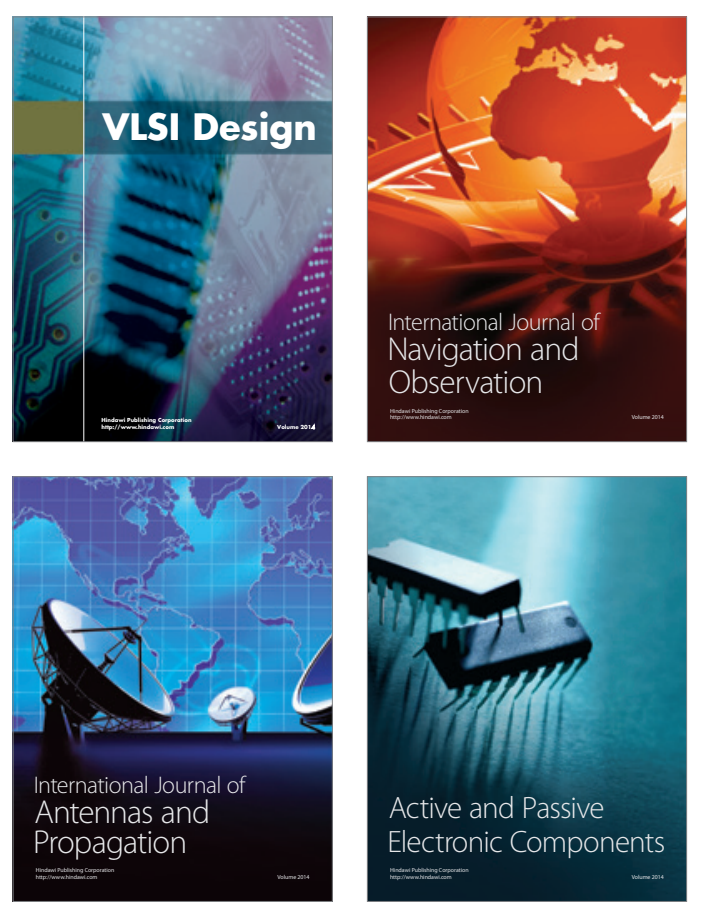
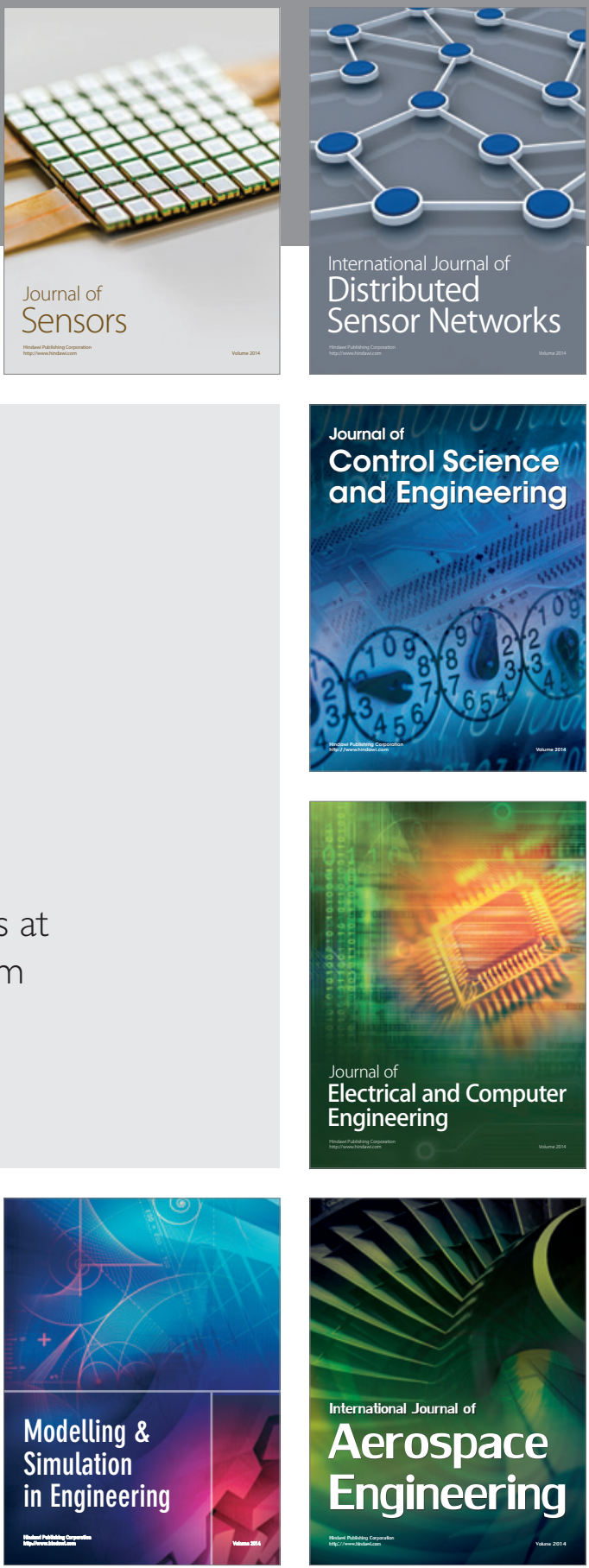

Journal of

Control Science

and Engineering
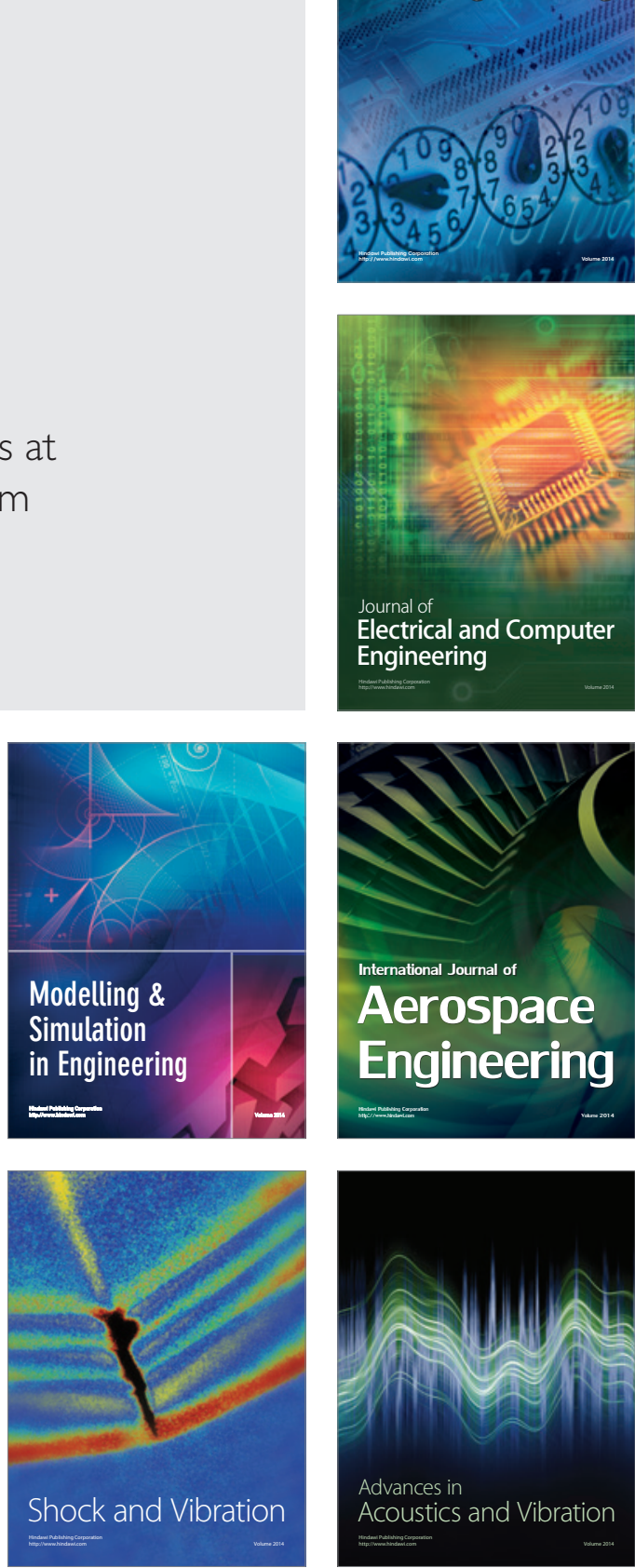